48.

\title{
LABOUR AND EMPLOYMENT SURVEYS OF THE DEPARTMENT OF STATISTICS \\ LEN COOK
}

\section{INTRODUCTION}

Labour and employment statistics result from surveys of : (a) individuats who are in the labour force, and (b) employers of labour (as identified through establishments).

The regular surveys that produce statistical data on individuals in the labour force, the Census of Population and the Household Survey, provide a wealth of statistical data on the economic and demographic characteristics of labour force members and their households. Industry, sector, and place of employment data is also obtainable from surveys of individuals, however the details on the activity of employing organisations collected in this way is limited. Specific one-off surveys may provide additional such data, as did the Social Indicators Survey of 1980-81.

\section{DATA ON INDIVIDUALS}

Table 1 presents surveys of individuals and lists the primary variables of interest. Variables associated with these are also listed and they typically include age, sex and marital status. The level of industrial and occupational classification is also shown together with the availability of institutional sector divisions. The lowest spatial scale available, the periods over which the survey is carried out, the population covered, the sampling fraction and date at which the series commenced combine to provide a ready reference for those in search of particular labour and employment data.

\section{THE CENSUS OF POPULATION}

The single most important source of labour and employment statistical data on individuals is the 5-yearly Census of Population. The Census records the occupation, hours worked, employment status, location and place of work data for every individual reporting in the Census. Income, education, age, sex, means of travel to work, address and other demographic characteristics of respondents are also available. Thus, individual census variables can be cross-tabulated for all or particular types of individuals, at national or sub-national leve1s down to meshblocks. 
Availability of census data The Department of Statistics has continued to increase the range of statistical data that can be economically produced in the Census of Population, as its access to suitable statistical packages and related computer facilities improves. Consequently, the range of published statistical series produced after each Census represents an increasingly minor portion of the data actually and potentially available to users. Ad hoc access to individual census records has now become sufficiently cost effective for tables to be tailored to the requirements of individual users. This is a considerable improvement over the published and unpublished multi-purpose tabulations produced as output from Population Censuses prior to 1976. Access to the 1981 Census records is available from the linking of CENTSAID package to the complete Census file or various Census sample files (10 percent, 5 percent, 1 percent). To enable economic access, the full Census file is available for subsets of : (1) all adults 15 and over; (2) all persons usually resident in New Zealand; (3) all persons aged 15 and over in the full-time labour force. A range of unpublished tables is also available on microfiche, as described in the 1981 Census "Labour Force" volume.

The range and availability of census statistics from the 1981 Census of Population and Dwellings A bulletin is currently being printed on the range and availability of statistical data from the 1981 Census of Population and Dwellings. The bulletin provides details on the Census publications that have been produced, listing tables that are available both in bulletins and volumes as well as those that are umpublished. Information on the definitions and concepts used in the 1981 Census is also provided.

The population census of 1986 To improve the relevance of the 1986 Census, all known users of the Census have been invited to submit proposals for revising census questions. Users have also been asked to comment on how they would like their output from the 1986 Census. Improved pre-testing of the 1986 Census questionnaires and better pilot testing of procedures, including the full control by the Department of Statistics of the enumeration of the Census for the first time should result in better quality of statistical data being collected. The Department of Statistics also is investigating the use of computer assisted coding methods which will improve the quality of coding and also allow the large amount of complex coding, particularly of labour-related data, such as industry and occupation, to be carried out more economically than at present.

Other issues that are being looked at, in the 1986 Census, include the possibility of a question on voluntary work, which has been a topic requested from a large number of submissions. This of course is subject to satisfactory pre-testing, given that the concept and a number of other submissions relevant to labour force, seem to be best met from a time-use survey rather than a self-enumerated population census. 
50.

TABLE 1 DEPARTMENT OF STATISTICS SURVEYS OF INDIVIDUALS

\begin{tabular}{|c|c|c|c|}
\hline & $\begin{array}{l}\text { CENSUS OF POPULATION } \\
\text { AND DWELLINGS }\end{array}$ & $\begin{array}{l}\text { HOUSEHOLD } \\
\text { SURVEY }\end{array}$ & $\begin{array}{l}\text { SOCIAL INDICATORS } \\
\text { SURVEY }\end{array}$ \\
\hline Primary variables & $\begin{array}{l}\text {-Hours worked } \\
\text {-Employment status } \\
\text {-Income } \\
\text {-Education } \\
\text {-Address } \\
\text {-Location of Workplace } \\
\text {-Means of trave1 to } \\
\text { work }\end{array}$ & $\begin{array}{l}\text {-Hours worked } \\
\text {-Employment status } \\
\text { - Income } \\
\text {-Enployment History } \\
\text { over last } 12 \text { months } \\
\text {-Expenditure }\end{array}$ & $\begin{array}{l}\text {-Hours worked } \\
\text {-Employment status } \\
\text {-Income } \\
\text {-Education } \\
\text {-Means of travel to } \\
\text { work } \\
\text {-Time to work } \\
\text {-Job satisfaction } \\
\text {-Job security } \\
\text {-Discouraged from } \\
\text { work } \\
\text {-Unsocial hours } \\
\text {-Weekend hours } \\
\text {-Shift work } \\
\text {-Preferred hours }\end{array}$ \\
\hline Associated variables & $\begin{array}{l}\text {-Age } \\
\text {-Sex } \\
\text {-Marital status } \\
\text {-Ethnic origin }\end{array}$ & $\begin{array}{l}\text {-Age } \\
\text {-Sex } \\
\text {-Marital status } \\
\text {-Ethnic group }\end{array}$ & $\begin{array}{l}\text {-Age } \\
\text {-Sex } \\
\text {-Marital status } \\
\text {-Ethnic group }\end{array}$ \\
\hline $\begin{array}{l}\text { Industrial class } \\
\text { (NZSIC) }\end{array}$ & 5 digit & 2 digit & 2 digit \\
\hline $\begin{array}{l}\text { Occupational class } \\
\text { (NZSCO) }\end{array}$ & 4 digit & 2 digit & 2 digit \\
\hline Institutional sector & 1 digit & nil & nil \\
\hline $\begin{array}{l}\text { Spatial scale - } \\
\text { lowest }\end{array}$ & Meshblock & nil & nil \\
\hline Periodicity & 5 yearly & Annual & Ad hoc \\
\hline Population covered & $\begin{array}{l}\text { Persons usually resi- } \\
\text { dent in NZ, age } 15 \\
\text { years and over }\end{array}$ & $\begin{array}{l}\text { Persons living in } \\
\text { private house- } \\
\text { holds }\end{array}$ & $\begin{array}{l}\text { Persons living in } \\
\text { private house- } \\
\text { holds }\end{array}$ \\
\hline Sample & $100 \%$ & $0.3 \%$ & $0.2 \%$ \\
\hline Series commenced & 1851 & 1974 & $1980 / 81$ \\
\hline
\end{tabular}




\begin{tabular}{|c|c|c|c|}
\hline $\begin{array}{l}\text { PERSONAL INCOMES } \\
\text { AND INCOME TAX }\end{array}$ & $\begin{array}{l}\text { REAL DISPOSABLE } \\
\text { INCOMES INDEXES }\end{array}$ & $\begin{array}{l}\text { EXTERNAL } \\
\text { MIGRATION }\end{array}$ & $\begin{array}{c}\text { PAY } \\
\text { RESEARCH }\end{array}$ \\
\hline $\begin{array}{l}\text {-Gross income } \\
\text {-Assessable income } \\
\text {-Tax paid } \\
\text {-Tax rebates } \\
\text {-Other incomes }\end{array}$ & $\begin{array}{l}\text {-Gross income } \\
\text {-Average tax rates } \\
\text {-Real disposable } \\
\text { incomes for quin- } \\
\text { tiles of wage and } \\
\text { salary earners }\end{array}$ & $\begin{array}{l}\text {-Country of birth } \\
\text {-Nationality } \\
\text {-Purpose of visit } \\
\text {-Length of stay/ } \\
\text { absence } \\
\text {-Class of migrant } \\
\text {-Country of last/ } \\
\text { next residence } \\
\text {-Port of embarkation/ } \\
\text { disembarkation }\end{array}$ & $\begin{array}{l}\text {-Taxable gross } \\
\text { income } \\
\text {-regular (wages, } \\
\text { salary) } \\
\text {-irregular } \\
\text { (wages, salary) } \\
\text { - Non-taxable gross } \\
\text { income } \\
\text {-regular } \\
\text {-irregular }\end{array}$ \\
\hline nil & nil & $\begin{array}{l}\text {-Age } \\
\text {-Sex } \\
\text {-Marital status }\end{array}$ & $\begin{array}{l}\text {-Age } \\
\text {-Sex }\end{array}$ \\
\hline Major industry & nil & nil & nil \\
\hline nil & ni1 & 3 digit & $\begin{array}{l}\text { Specific } \\
\text { benchmark }\end{array}$ \\
\hline ni1 & nil & nil & Private/State \\
\hline Tax district & nil & $\begin{array}{l}\text { Statistical } \\
\text { Area }\end{array}$ & $\begin{array}{l}\text { Employment } \\
\text { District }\end{array}$ \\
\hline Annual & Quarterly & Monthly & Ad hoc \\
\hline Tax returns & $\begin{array}{l}\text { Full-time wage and } \\
\text { salary earners in } \\
\text { private house- } \\
\text { holds }\end{array}$ & Migrants & $\begin{array}{l}\text { Employees in } \\
\text { selected } \\
\text { occupations }\end{array}$ \\
\hline 28 & $0.3 \%$ & $\begin{array}{l}\text { Permanent and long- } \\
\text { term } 100 \% \text {, short- } \\
\text { term } 25 \%\end{array}$ & $\begin{array}{l}\text { Sample to full } \\
\text { coverage }\end{array}$ \\
\hline 1922 & 1980 & 1934 & $\begin{array}{l}1979 \text { (re- } \\
\text { established) }\end{array}$ \\
\hline
\end{tabular}


The Department is also looking at providing access to Census data in the form of index or summary files as is available in the United States and Canada. The summary files, some of which will be available on INFOS, will also be available to users to link to statistical packages such as SAS which together with associated digitised boundaries will provide a powerful facility for the mapping of census output. The Government has approved the purchase by the Department of Statistics of an IBM 4361 computer for the processing of the 1986 Census. This will be installed in late September 1984. The new computer facilities will allow TPL to be linked to the 1981 and 1986 Census data files. An easy-to-use interface to TPL has already been developed, which will expedite the production of publication quality tables for users.

Population projections and estimates 1981 Census-based labour force participation rates will be available very shortly. These rates will include for the first time, estimates of part-time labour force participation rates, and projections of the part-time labour force. Regional projections of the labour force will be available from July 1984 .

\section{OTHER SURVEYS}

Data on individuals from the interviewer-based Household Survey and the Social Indicators Survey are available by employment status, hours worked, income, employment history, and many other related variables for individuals in the work force. The Social Indicators Survey, in particular, has collected information on job satisfaction, job security, discouraged work, "unsocial" hours, weekend hours, shift work and preferred work hours of respondents. Whilst these surveys only provide national estimates and limited-depth industry and occupation analyses, they do provide some indication of the distribution of responses to employment variables according to demographic and other characteristics.

Extensive cross-section analyses are possible with the Census and Household Surveys and Social Indicators data collections. One recent study has been a 1 and 2 income family study by Wigbout and Penhale which identified those factors which differentiate 1 income families from those with 2 incomes (see scholarsly periodicals section of bibliography).

Personal incomes and income tax statistics have been available since 1922. An occupation analysis has not been carried out of personal income tax respondents for some years. The information is available for self-employed persons by industry of their income, both gross and assessable with a regional analysis being by tax district.

The real disposable income indexes have been produced to provide real disposable income movements for wage and salary earners at different income levels. The 
only analysis available is by quintile group with indexes based on the responses to the Household Sample Survey of 1980-81. The incomes collected at that time have been adjusted by indicators which are correlated with the quarterly movements of the major sources of income as adjusted by the tax rates relevant to each particular period. These data are only available at the national level however.

External migration data provides information on the flows of individuals from overseas into the work force and New Zealanders leaving the local work force. The main information available is age, sex, marital status and occupation of migrants.

Pay Research Surveys provide information related to persons on specific benchmarks in both the private and state sector in New Zealand. There is no aggregate comparison produced of persons in the State and private sector from the Pay Research Surveys. Rather, the value of a range of individual components of remmeration in the form of regular wages and salaries, irregular income and allowances are measured for individuals in both the public and private sector. During the course of industrial negotiations, measures are made of their relative importance to the desired differentials between State and private wages.

At the time of writing New Zealand has no labour force survey. On 3 occasions the Government Statistician has recommended to Government that finance be available for such a survey, but the required compensatory savings have not been able to be made.

\section{DATA ON ESTABLISHMENTS}

By contrast with the sources of data on individuals, surveys of establishments provide comparatively exact specifications of the industry sector and place of employment. Department of Statistics surveys of employers providing 1abour and employment statistics are as follows : (1) Prevailing weekly wage rates index;

(2) Nominal weekly wage rates index; (3) Pay Research Surveys; (4) Census of Agriculture; (5) Agriculture Economic Surveys; (6) The Integrated Economic Censuses; (7) The Quarterly Manufacturing Survey.

Table 2 sets out the 7 sources in a comparable manner to Table 1 . The primary variables of interest are indicated and these are broken down by industrial and occupational classification. Again, information on the spatial scale, population and sampling fraction will be of assistance to those examining the sources of employment in New Zealand. Each source will now be briefly discussed.

\section{WAGE RATE INDEXES}

The Department of Statistics has produced nominal wage rate indexes since 1909 and indexes of prevailing weekly wage rates since 1977. The key breakdown of the index is of awards settled by the Arbitration Court and of other tribunals. Some 
54.

TABLE 2 DEPARTMENT OF STATISTICS SURVEYS OF ESTABLISHMENTS

\begin{tabular}{|c|c|c|c|c|}
\hline . & $\begin{array}{l}\text { WEEKLY WA } \\
\text { NOMINAL }\end{array}$ & $\begin{array}{l}\text { INDEXES } \\
\text { PREVAILING }\end{array}$ & $\begin{array}{l}\text { AGRICULTURAL } \\
\text { ECONOMIC } \\
\text { SURVEYS }\end{array}$ & $\begin{array}{c}\text { CENSUS } \\
\text { OF } \\
\text { AGRICULTURE }\end{array}$ \\
\hline Primary variables & $\begin{array}{l}\text { Award wage rate } \\
\text { movements }\end{array}$ & $\begin{array}{l}\text { Prevailing wage } \\
\text { rate movements }\end{array}$ & $\begin{array}{l}\text { No. of persons } \\
\text { by employment } \\
\text { status } \\
\text { Wages and } \\
\text { salaries }\end{array}$ & $\begin{array}{l}\text { No. of persons } \\
\text { by employment } \\
\text { status } \\
\text { Wages and } \\
\text { salaries }\end{array}$ \\
\hline Associated variables & \multicolumn{2}{|c|}{ Arbitration Court/Other Tribunal } & nil & nil \\
\hline $\begin{array}{l}\text { Industrial class } \\
\text { (NZSIC) }\end{array}$ & \multicolumn{2}{|c|}{2 digit } & 9 farm types & 5 digit \\
\hline $\begin{array}{l}\text { Occupational class } \\
\text { (NZSCO) }\end{array}$ & \multicolumn{2}{|c|}{ major group } & nil & nil \\
\hline $\begin{array}{l}\text { Spatial scale - } \\
\text { lowest }\end{array}$ & \multicolumn{2}{|c|}{ nil } & nil & county \\
\hline Periodicity & \multicolumn{2}{|c|}{ Quarterly } & Annual & Annual \\
\hline Population covered & \multicolumn{2}{|c|}{$\begin{array}{l}\text { Employees covered by awards of } \\
\text { Arbitration Court and other } \\
\text { deternining authorities }\end{array}$} & $\begin{array}{l}\text { Selected } \\
\text { farm types }\end{array}$ & Farms \\
\hline Sample & $\begin{array}{l}\text { Ful1 coverage } \\
\text { of awards and } \\
\text { other determin- } \\
\text { ing authority } \\
\text { minima }\end{array}$ & $\begin{array}{l}\text { Sample of } \\
\text { enterprises }\end{array}$ & $\begin{array}{l}\text { Ful1 coverage } \\
\text { of some farm } \\
\text { types and } \\
\text { sample of } \\
\text { others }\end{array}$ & Full coverage \\
\hline Series commenced & 1909 & 1977 & 1981 & 1842 \\
\hline Series terminated & - & - & - & - \\
\hline
\end{tabular}




\begin{tabular}{|c|c|c|c|}
\hline $\begin{array}{l}\text { PRODUCTION } \\
\text { CENSUS }\end{array}$ & $\begin{array}{l}\text { INTEGRATED } \\
\text { ECONOMIC } \\
\text { CENSUSES }\end{array}$ & $\begin{array}{l}\text { QUARTERLY } \\
\text { MANUFACTURING } \\
\text { SURVEY }\end{array}$ & $\begin{array}{l}\text { QUARTERLY ECONOMIC } \\
\text { SURVEY OF } \\
\text { DISTRIBUTION }\end{array}$ \\
\hline $\begin{array}{l}\text { No. of persons } \\
\text { engaged } \\
\text { Wages and } \\
\text { salaries }\end{array}$ & $\begin{array}{l}\text { No. of persons } \\
\text { by employment } \\
\text { status } \\
\text { Wages and } \\
\text { salaries }\end{array}$ & $\begin{array}{l}\text { Total hours } \\
\text { worked } \\
\text { Total wages } \\
\text { and salaries }\end{array}$ & $\begin{array}{l}\text { Total hours } \\
\text { worked } \\
\text { Total wages and } \\
\text { salaries }\end{array}$ \\
\hline nil & nil & nil & nil \\
\hline 3 digit & 5 digit & 2 digit & $\begin{array}{l}2 \text { digit } \\
(61,62,63 \text { \& 95) }\end{array}$ \\
\hline nil & nil & nil & nil \\
\hline $\begin{array}{l}\text { Local Authority } \\
\text { (incl Employment } \\
\text { District) }\end{array}$ & Meshblock & nil & nil \\
\hline Annual & $\begin{array}{l}5 \text { yearly } \\
\text { (manufacturing } \\
2 / 3 \text { yearly) }\end{array}$ & Quarterly & Quarterly \\
\hline Manufacturers & Industries & Manufacturers & $\begin{array}{l}\text { Retailing, } \\
\text { Wholesaling, } \\
\text { Accommodation } \\
\text { and Service } \\
\text { Enterprises }\end{array}$ \\
\hline Full coverage & Full coverage & $\begin{array}{l}\text { Full coverage } \\
\text { of large manu- } \\
\text { facturers and } \\
\text { sample of } \\
\text { others }\end{array}$ & $\begin{array}{l}\text { Full coverage } \\
\text { of large enter- } \\
\text { prises and } \\
\text { sample of } \\
\text { others }\end{array}$ \\
\hline 1918 & 1974 & 1977 & 1984 \\
\hline 1974 & - & - & - \\
\hline
\end{tabular}


users identify this distinction as a public/private sector breakdown. This is not correct. The Arbitration Court does hear awards for employees not in the private sector and there are a number of non-public sector awards heard by the other tribunal group. The industry analysis for the indexes is a 2-digit level and the occupational analysis is at a 1-digit leve1.

The sample coverage is such that a more detailed analysis would not be possible. The prevailing weekly wage rates index is currently being reviewed in order to examine whether the range of employee remueration can be extended beyond that of wage rates as at present. Difficulties are encountered as more and more remuneration comes in a form other than wage rates." Noteworthy here are particular productionrelated bonuses which vary as the level of production varies and therefore cause some difficulties with these indexes. The forthcoming publication, wages and earnings, contains technical data on the Nominal and Prevailing Weekly Wage Rate Indexes, as well as an historical series.

\section{OTHER ESTABLISHMENT SURVEYS}

The other surveys which are noted in Table 2 (Agriculture Economic Surveys, the Census of Agriculture, the Production Censuses, Integrated Economic Censuses, the Quarterly Manufacturing Survey, and the Quarterly Economic Survey of Distribution) are not designed specifically for the collection of employment-related data. Information on wages and salaries and number of persons engaged is collected as part of a wider set of statistics collected from the establishment. For the Censuses of Agriculture, the Production Census and the Integrated Economic Censuses, the data is available at a fine level of geographic detail.

Integrated Economic Censuses refers to the following set of 8 :

$\begin{array}{ll}\text { Census of Agriculture Contracting Services } & 1979-80 \\ \text { Census of Building and Construction } & 1978-79 \\ \text { Census of Distribution } & 1977-78 \\ \text { Census of Fishing } & 1980-81 \\ \text { Census of Forestry and Logging } & 1979-80 \\ \text { Census of Manufacturing } & 1978-79 \\ \text { Census of Mining and Quarrying } & 1978-79 \\ \text { Census of Services } & 1980-81\end{array}$

\section{REVIEW OF LABOUR STATISTICS}

Labour and employment statistics have been under review for some time. When made available to users, the review report will provide a wealth of information on the characteristics of surveys pertinent to users of labour and employment statistics. The current range of labour and employment statistics is explored as is their 
classification, their periodicity and their availability. The relevance of a labour force survey will be considered in light of these findings together with specific concerns such as whether ethnic data should be available for persons who register as unemployed. Now is the time for users of labour statistics to articulate their concerns about their ability to use and integrate data from different surveys and to link data from the same survey over different time periods. 